\title{
Thoughts on the Role of Teachers in University Running
}

\author{
Lin $\operatorname{Lin}^{1, a}$ \\ ${ }^{1}$ Institute for Higher Education, Jilin Agricultural University, Changchun,130118, China, \\ aemail: linlinjlau@126.com
}

Keywords: University; Teacher; Central position; Teachers' development

\begin{abstract}
The relationship between university running and teachers have gradually become the focus of attention. It is often seen that university management mechanism causes adverse effect on teachers' development and teachers hinder university running and development in return. Therefore, teachers plays a crucial role in realization of university functions, promoting university management and enhancing quality of talent cultivation.
\end{abstract}

\section{Origin of the Problem}

University running and teacher's development is inter-dependent and mutually-promoting. Since the appearance, schools and teachers are a group accompanying each other. Among all the elements for university running, personnel factor, namely teachers in the university are the most critical factor ${ }^{[1]}$. During progress of modern education, it is not to be wondered at university running and teachers' development restraining each other. On the one hand, university management mechanism restricts teachers' development; and on the other hand, teacher factors bound university running and development.

\section{The Role of Teachers in University Running}

Mei Yiqi, former president of Tsinghua University said in his inauguration speech in 1931 that: "What makes a good university is the amount and quality of masters it owns, instead of the amount and quality of buildings that stands". In modern society, quality and quantity of teachers have not only become an important standard measuring quality of a university but also one of the core standards for beginning of university running and development of its core competitiveness. Core competitiveness of a university includes many elements, namely: the functional elements, such as scientific research, talent cultivation and social service; the organizational elements playing a guiding and coordinating role, such as system and management; and the deep factors, such as philosophy and academic atmosphere of the university. Thus, teachers are the most important element and the prime resource for university running.

\subsection{Teachers are the strong guarantee for realization of functional elements of the university}

Today, a new round of comprehensive reform in university has been increasingly deepened, and the reform of higher education has stepped into the later stage. Under this circumstance, in order to fulfill the functions of talent cultivation, scientific research, social service and cultural inheritance and set foot in the main battlefield witnessing rapid development of higher education, universities shall take a road of connotative development and strive to improve quality of talent cultivation. In this process, teachers shall be regarded as the focus and strong guarantee for improving quality of talent cultivation. Faculties are the main participants of professional construction of discipline, academic and scientific research and their knowledge reserve, academic attitude, academic vision, and capability for scientific research directly influence prospects and progresses of scientific research of the university; faculties are the initiators of social service, who serve in social activities through personal practice or stimulating and guiding students, and help the university in achieving mutual benefits with the society through their wisdom; teachers are the mainforce of cultural inheritance and forerunners of cultural innovation. Especially, as the organizer and executors of teaching activities of the university, faculties' ethics, knowledge architecture, 
professional competence, teaching method, and professional dedication directly influence teaching quality and teaching results, thus affect the social reputation and school running level. On this ground, teachers are the core element for realizing four functions of a university ${ }^{[2]}$.

\subsection{Teachers are the necessary organizational element for systematic management of the university}

University management is mainly realized by organization and implementation of its rules and regulations, firstly, in the course of establishment of the rules and regulations for the university, opinions and suggestions of the object of management -- teachers shall be taken. Only by allowing teachers to involve in determination of the systems, they may give support and understanding during implementation of the rules and regulations under full guarantee of their right to know and participation right. That is good for helping the rules and regulations taking effect, group harmony, and giving full play to the faculty's important role in engaging in university governance. Secondly, it is the fundamental requirement of democratization of higher education management to allow teachers to engage in systematic management. In university management, the practice of " deciding everything by one man's say" shall be discarded and the modern road of democratization and de-administration for development shall be taken. According to the Teacher's Law and Higher Education Law, teachers have the right to bring forward an opinion on the regulations issued by the school and to engage in school management. The faculty's engagement in the university management is the basic path for realization of democratization and the fundamental guarantee for improving management efficiency, optimizing organization atmosphere, and promoting self-development of the faculty. In a word, without the faculty's participation, democratic management of the university can never be achieved ${ }^{[3]}$.

\subsection{Teachers are the pushers of the philosophy, academic atmosphere and other deep factors of the university}

The faculty's intensive knowledge reserve, profound theoretical basis and rich practical experience are the key points for coordination of theory and practice, higher leadership and students on campus, state-should-be and practical state of university running. Teachers push forward overall operation of the university while performing their various duties, for they have deeper and thorough understanding of the philosophy and culture, value orientation of the university and more realistic feelings of teaching reality and student life. They not only assume the important teaching task of talent cultivation but also shoulder the responsibility of educating students, that is to say, they shall develop, educate and impact students on cultural qualities, moral integrity, physical and mental health by behavior modeling or exerting subtle influence in teaching activities or campus life. Needless to say that, teachers play a decisive role in elements at the spiritual level such as construction of campus culture and value guidance in university running.

\section{Dominant position of teachers shall be attached to high importance in university running}

\subsection{To erect a platform to promote teacher's professional development}

For university running, the concept of "teacher-oriented" shall be set up, and a platform for faculties shall be erected to realize their lifelong ideal, so as to help and promote their professional development. With regard to academic aspects, it is necessary to create an atmosphere of academic freedom and learning first, and hand over the academic authority to the faculties to enable them to decide academic issues on the majors, disciplines and courses, independently carry out and advance academic studies, and regard learning as their vocational pursuit so as to enhance teaching quality. Besides, in terms of professional development, more opportunities for academic exchanges and training shall be provided for faculties to promote their vocational development and progress so that they can gain happiness in the course of vocational development, enjoy pride from realizing their 
own value, and then regard professional development as a lifestyle and a life pursuit. Only by finding where their value lies, can the faculties throw themselves into work with full academic enthusiasm and promote improvement of teaching quality and university development ${ }^{[4]}$.

\subsection{To establish "teacher-oriented" scientific management system}

The dominant dominant position of teachers in university running shall be given high importance: firstly, a scientific management system shall be established, to ensure that the faculties can give full play to their dominant position by system design. Secondly, certain conditions shall be provided to help faculties in growth and development so as to drive and push forward university development by improvement of their competence. Thus, whether a university adheres to the policy of "teacher-oriented" in its running can be measured from two aspects: first, the quality of faculty as the basic condition of university running; second, whether the faculty team pushes forward university development by growth of itself. So, how to provide conditions, erect platform, innovate carrier, facilitate teachers in producing more remarkable outcomes? Of course, a scientific management system is indispensable. The key point lies in establishing and perfecting a scientific and effective teacher evaluation system that no longer focuses merely on academic and scientific research results but both on scientific research and teaching quality. For this reason, the evaluation system shall both cover scientific research and teaching efficiency and avoid to repeat the mistake of judging only by scientific research results. Especially, under the overall context of high importance attached to scientific evaluation, the fundamental factor of teaching itself can never be abandoned. Without high-quality teaching, it is hardly possible to cultivate excellent students or improve school-running level of the university. In addition, the evaluation system shall attach importance to evaluation and reflection of teaching efficiency, especially in confering of academic titles, promotion in rank, appraising and selecting the most outstanding individual, so as to facilitate mutual progress of teaching quality and scientific research of teachers ${ }^{[5]}$.

\subsection{To offer meticulous humanistic care}

According to a survey on health of teachers in universities conducted by a province, about $10 \%$ of the teachers surveyed are basically healthy, about $20 \%$ of the teachers surveyed are sick and $70 \%$ of the teachers surveyed are in sub-health status. Besides, due to factors including university management, harsh system replaces humanist management and the pursuit of quantization and evaluation suppress the personality and ideas of most young teachers, which result in relatively strong physical fatigue and psychological stress on teachers in universities. In fact, teachers in universities are over stressed by teaching and scientific research tasks, confering of academic titles and promotions, interpersonal relations, vocational development and their families. Being under pressure and sub-health status for a long time makes it a common phenomenon for occupational burnout of teachers in universities.

High importance shall be attached to such phenomenon in university running, and management ans service departments at all levels of the university shall strengthen the service awareness of teachers-oriented and give meticulous humanistic care to teachers. What' s more, teachers shall be regarded as precious treasures and resources of the university and given to full care and respect so as to protect their personality, help them to carry out teaching activities and scientific researches and arouse their enthusiasm and creativity. A reward mechanism shall be set up with exemplary teaching award for commending the outstanding individuals and groups in teaching reform. Besides, those who win the award is given to priority in professional title promotion to encourage them to devote themselves to teaching; In the distribution mechanism, teachers shall be provided with some privileges and the principle of priority in efficiency and fair competition shall be exerted to allow teachers realize more pay for more work; in terms of daily life, teachers shall be provided with meticulous care from conditions of teaching and scientific research, housing conditions, difficulties in life to help them ans solve their worries behind thus they can focus on teaching and scientific research, keep their mind on study, make progress with high concentration, and make contribution 
to development of the university.

\section{References}

[1] Sheng Zitong, A Stretegy Research on Win-win Development of Teachers and Universities [D], Fuzhou : Fujian Normal University, 2007;

[2] Cui Chun, A Study on Problems in Sino-Foreign Cooperative Education for Agricultural and Forestry Universities [D]: Changchun: Northeast Normal University, 2014

[3] Ma Tingqi, On Teaching Responsibility of Teachers in Universities [J], Journal of Higher Education, 2008(5) :20 - 25;

[4] Yang Yi, A Study on Change of Employment System of Teachers in Universities in New China [D]: Chongqing, Southwest University, 2013;

[5] Li Juan, The Relationship between Universities and Teachers From the Perspective of Contract Theory [D]: Fuzhou: Fujian Normal University, 2010 